\title{
Pituitary stalk interruption syndrome
}

\author{
Shiva Kumar Gosi, ${ }^{1}$ Swetha Kanduri, ${ }^{2}$ Vishnu Vardhan Garla ${ }^{2}$
}

${ }^{1}$ Banner Thunderbird Medical

Center, Glendale, Arizona, USA

2Department of Internal

Medicine, University of

Mississippi Medical Center,

Jackson, Mississippi, USA

Correspondence to

Dr Vishnu Vardhan Garla,

vishnu.garla@gmail.com

Accepted 29 March 2019

\section{DESCRIPTION}

A 21-year-old male patient presented to the endocrine clinic with a history of congenital hypopituitarism. He had adrenal insufficiency, hypothyroidism and hypogonadism, which were being adequately replaced. At age 4, he was brought to the clinic with failure to thrive and small stature. He had no significant medical history or family history of short stature. Laboratory assessment revealed hypoglycaemia, low thyroxine, cortisol and adrenocorticotrophic hormone consistent with adrenal insufficiency. Growth hormone stimulation test revealed growth hormone deficiency. $\mathrm{He}$ was started on steroid, thyroid and growth hormone replacement. MRI of the pituitary gland (figure 1) showed an atrophic pituitary gland, absent pituitary stalk and an ectopic posterior pituitary consistent with pituitary stalk interruption syndrome (PSIS).

PSIS is a congenital abnormality characterised by a triad of thin or interrupted pituitary stalk, small or absent pituitary gland, and an absent or ectopic pituitary gland. It was first described in 1987 by Fujisawa $e t$ al and had a reported incidence of $0.5 / 100000$ births. $^{12}$ PSIS is believed to be either due to mutations in the genes involved in pituitary embryogenesis (PROP1, LHX3, HEXSX1, PROKR2 and GPR161) or perinatal asphyxia. PSIS can present with anterior pituitary hormone deficiencies (growth hormone, 100\%; gonadotropin, $97.2 \%$; corticotropin, $88.2 \%$; and thyrotropin, 70.3\%); however, hyperprolactinaemia (6.9\%) due to lack of dopaminergic inhibition can be seen. Posterior pituitary function is intact. These anterior pituitary hormonal deficiencies can present as hypoglycaemia, neonatal jaundice, short stature, cryptorchidism, delayed puberty and micropenis. PSIS is also associated with other midline defects,

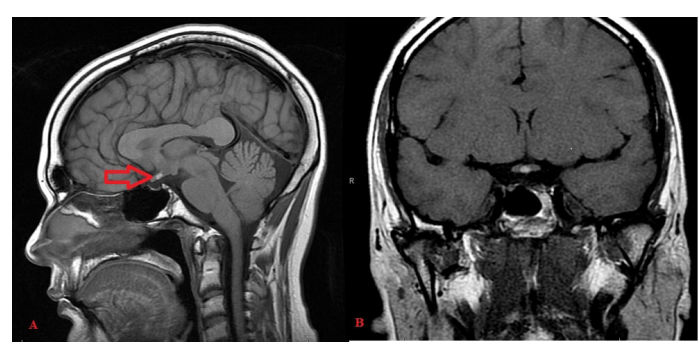

Figure 1 (A) T1 sagittal image showing an atrophic pituitary gland and a $5 \mathrm{~mm}$ hyperintense focus in the retrochiasmatic region, which represents the ectopic posterior pituitary gland (red arrow). (B) T1 coronal image showing non-visualisation of the pituitary stalk. such as broad nose, cleft lip and palate, single incisor, and nasal aperture stenosis. ${ }^{3}$ MRI shows the characteristic triad of absent pituitary stalk, anterior pituitary hypoplasia (98.3\%) and ectopic posterior pituitary (91.2\%). The ectopic neurohypophysis is most commonly seen in the infundibular recess $(60.4 \%)$ or the hypothalamus $(18.9 \%){ }^{4}$ PSIS is a rare condition and international databases need to be established to further study the molecular aetiology.

\section{Learning points}

- Pituitary stalk interruption syndrome is a congenital abnormality of the pituitary gland consisting of the triad of thin or interrupted pituitary stalk, small or absent anterior pituitary gland, and an absent or ectopic pituitary gland

- It is characterised by deficiencies in the hormones secreted by the anterior pituitary gland, however mild hyperprolactinaemia may be seen. This is secondary to dopamine being unable to reach the pituitary and inhibit the lactotrophs as there is no pituitary stalk.

- Clinically, it is characterised by hypoglycaemia, delayed puberty, short stature, micropenis, cryptorchidism and visual defects.

- MRI is diagnostic showing an absent pituitary gland and an ectopic posterior pituitary.

Contributors SK and SKG were involved in writing the manuscript. VVG was the senior author involved in editing the manuscript.

Funding The authors have not declared a specific grant for this research from any funding agency in the public, commercial or not-for-profit sectors.

Competing interests None declared.

Patient consent for publication Not required.

Provenance and peer review Not commissioned; externally peer reviewed.

\section{REFERENCES}

1 Arrigo T, Wasniewska M, De Luca F, et al. Congenital adenohypophysis aplasia: clinical features and analysis of the transcriptional factors for embryonic pituitary development. J Endocrinol Invest 2006;29:208-13.

2 Fujisawa I, Kikuchi K, Nishimura K, et al. Transection of the pituitary stalk: development of an ectopic posterior lobe assessed with MR imaging. Radiology 1987;165:487-9.

3 Wang CZ, Guo LL, Han BY, et al. Pituitary Stalk Interruption Syndrome: From Clinical Findings to Pathogenesis. J Neuroendocrinol 2017;29.

To cite: Gosi SK, Kandu
Garla VV. BMJ Case

Rep 2019;12:e230133.

doi:10.1136/bcr-2019-

230133
4 Yang Y, Guo QH, Wang BA, et al. Pituitary stalk interruption syndrome in 58 Chinese patients: clinical features and genetic analysis. Clin Endocrinol 2013;79:86-92. 
Images in...

Copyright 2019 BMJ Publishing Group. All rights reserved. For permission to reuse any of this content visit https://www.bmj.com/company/products-services/rights-and-licensing/permissions/

BMJ Case Report Fellows may re-use this article for personal use and teaching without any further permission.

Become a Fellow of BMJ Case Reports today and you can:

- Submit as many cases as you like

- Enjoy fast sympathetic peer review and rapid publication of accepted articles

Access all the published articles

- Re-use any of the published material for personal use and teaching without further permission

For information on Institutional Fellowships contact consortiasales@bmjgroup.com

Visit casereports.bmj.com for more articles like this and to become a Fellow 